\title{
A bolognai képzés első tapasztalatai a némettanár-képzésben (2012)
}

\author{
Petneki Katalin \\ Szegedi Tudományegyetem
}

\begin{abstract}
A Szegedi Tudományegyetem Bölcsészkarán a többi hazai intézményhez hasonlóan 2010-ben áttértek a kétszintủ tanárképzésre. Ennek lényege abban állt, hogy a BA szintű képzésbe sok diák bekerülhetett, de innen továbbtanulni már csak felvételi után lehetett, így oda már jóval kevesebben kerülhettek be. A tanári mesterszakra készülőknek pedig már a BA képzés során fel kellett venniük néhány pedagógiai jellegü kurzust, bár ezt utólag is pótolhatták. Az első „bolognás” évfolyam végén felmérést végeztem a némettanár szakos hallgatók körében, hogy mit gondolnak az új képzésröl. Ehhez hét kérdést fogalmaztam meg nekik, a nyolcadik pontban pedig szabadon fejthették ki véleményüket. Célom az volt, hogy visszajelzést kapjak a frissen végzettektől, hogy miképp értékelték az újfajta képzést. Jóllehet, mire az első ciklus a végéhez ért, már tudni lehetett, hogy nem marad meg ez a képzési forma, azért a diákok válaszai tartalmaznak tanulságos elemeket, amiket később is érdemes megszívlelni.
\end{abstract}

Kulcsszavak: Bolognai rendszerủ tanárképzés, mesterképzés, némettanár-szak

\section{Bevezetés}

Alig fejezte be az első mesterszakos tanárjelölti évfolyam tanulmányait, alig hogy odakerült a tanári képesítő vizsgabizottság elé, máris elkezdődött a kivonulás a bolognai folyamatból. Szegeden 2007-ben indult meg a bolognai rendszerü képzés BA szinten, így a 2010 szeptemberi félévben kezdték meg MA tanárszakos tanulmányaikat az első „bolognás” hallgatók. Azt már a bevezetésekor látni lehetett, hogy az a mód, ahogy ezt bevezették, nem fog müködni, bár ennek oka nem feltétlenül a bolognai rendszer hibája, és itt ennek elemzésére most nincs is mód. Már a 90-es évek második felében körvonalazódtak modellek, hogy miképp lehetne a rendszerváltáskor elindított 3 éves nyelvtanárképzésre építeni egy bolognai rendszerű mesterképzést (Bárdos és Medgyes, 1997; Szépe, 1997), ámde az egységes tanárképzésben a többi tantárgyaknál nem látszott hajlandóság hasonló programok kidolgozására. Pedig az 1989-90-ben angolból és 1990-91-ben németből az ELTE-n elindított hároméves nyelvtanárképzési programok visszhangja nagyon jó volt mind a diákok, mind a nemzetközi szakvélemény körében. Az ELTE-n a hároméves némettanár-képzés első szakaszát lezáró konferencia kötete (Petneki, Schmidt és Szablyár, 1994) például több nemzetközi hivatkozásban is megjelent ${ }^{6}$. Egyedül a hazai felsőoktatás berkein belül nem tudott magának kellő

\footnotetext{
${ }^{6}$ A hároméves képzés első tapasztalatait összegző konferenciakötetre később számos német szerző (pl. Hans-Jürgen Krumm 1996, Dietmar Rösler 2001) hivatkozott. A konferencia nyomán a kötet szerzői egyegy tanulmányt közölhettek a Fremdsprache Deutsch folyóirat „Neue Wege in der Deutschlehrerausbildung” címü, 1994-es kiadású különszámában.
} 
tekintélyt kivívni, hiába igyekeztek a képzést felépítő kollégák eredményeiket hazai és nemzetközi konferenciákon és publikációkban közzétenni. A 2007-ben elindított egységesítés elsősorban a takarékosságot szolgálta: legyen sok BA-s hallgató, akik közül aztán csak kevesen kerülhetnek be a drágább mesterképzésbe.

\section{A némettanári mesterképzés kiértékelése}

A képzési programok kidolgozása a kimeneti képesítési követelmények megfogalmazása után 2007-ben kezdődött el a 15/2006 (IV. 3.) OM rendelet 4. számú melléklete alapján. Ezek a követelmények magas szintü elvárásokat állítottak a leendő tanárok elé. Az öt félév alatt megszerezhető kreditek egyenlő súllyal szerepeltek a két tantárgy szakja és a pedagógia között elosztva, de az a rendeletből nem derült ki, hogy ezeket a magas követelményeket miképp lehet teljesíteni ennyire rövid idő alatt.

Mivel én voltam a némettanár-szak akkreditációs anyagának egyik szegedi megfogalmazója, már a program készítésekor elhatároztam, hogy megpróbálom kiértékelni az első évfolyam tapasztalatait. Azért is tartottam ezt fontosnak, mert mire ez az első MA-s évfolyam befejezte tanulmányait, addigra épp nyugdíjba mentem, s gondoltam, hogy ennek utódom is hasznát veheti. Igazán kiértékelni a képzést valóban csak ezen az egy, kis létszámú évfolyamon lehet, mert felmenő rendszerben néhány év alatt várhatóan megszünik ez a képzési forma.

\section{A felmérés módszere}

Egy, a CooSpace-ben ${ }^{7}$ közzétett kérdéssorral fordultam végzős hallgatóimhoz a tanári záróvizsga után, hogy foglalják össze, miképp ítélik meg a tanári mesterképzés két és fél évét. Ehhez nyolc kérdést fogalmaztam meg, amit e-mailben válaszoltak meg a frissen végzett diákok.

A kérdések foglalkoznak a bemenettel - az MA képzésre már felvételi vizsgát kellett tenniük a jelentkezőknek - a BA tanulmányok során tanultak felhasználhatóságára, az MA-kurzusok minőségére, a gyakorlati képzésre és lehetőség volt szabadon is gondolatokat hozzáfüzni. Célom az volt, hogy az osztatlan képzés visszaállításakor lehetőleg már ne kerüljenek be a rendszerbe olyan problémák és anomáliák, mint amiket a bolognai rendszer bevezetésekor tapasztalni lehetett.

\section{A válaszok kiértékelése a kérdések sorrendjében}

A kérdéssort megkapták mind a nappali, mind a levelező képzés végzősei. A diákok nem mindegyik kérdésre válaszoltak, így egy-egy kérdésnél eltérö számú válaszok keletkeztek. Most csak a 2012 őszi félév végén nappali képzésben résztvevő 12 diák

\footnotetext{
${ }^{7}$ Az SZTE-n használt egységes tanulmányi rendszer (ETR) online oktatási-tanulási felülete.
} 
válaszait foglalom össze a kérdések sorrendjében. Úgy gondolom, hogy ilyen kis létszámú csoport esetében nincs sok értelme számszerüsíteni a válaszokat, inkább a tendenciákat emelem ki.

Amikor a BA képzésbe jelentkezett, mennyire volt határozott elképzelése arról, hogy mi akar lenni? Mikor döntötte el, hogy a tanárszakot választja (esetleg miért)?

Ezt a kérdést azért tartottam fontosnak, mert a „Bologna” bevezetését a tanárképzésbe azzal indokolták, hogy sokan túl korán, ,éretlenül” döntöttek a tanárszak mellett. A korábbi tapasztalat pedig az volt, hogy szinte csaknem mindenki tanárszakot végzett a modern filológia szakosok közül, de csak kevesen mentek el végül tényleg a közoktatásba nyelvtanárnak. A válaszokból az derült ki, hogy ez a feltevés nem volt egészen helytálló.

Csupán egyetlen diák válaszolta azt, hogy nem voltak konkrét elképzelései, és csak a magasabb szintü diploma vonzotta a továbbtanulásra. A többi válaszadó kivétel nélkül mind elkötelezetten, már a BA-ba való jelentkezésekor is tudta, hogy tanár szeretne lenni. Volt, aki kifogásolta, hogy nem tudott rögtön, a kezdetektöl fogva a tanári pályára készülni. Többen említették, hogy a tanári pályára saját korábbi tanáruk példája irányította, a tanár személye példaképül szolgált.

A BA képzésben tanultakra, ott felvett kurzusokra mennyire tudott támaszkodni később az MA tanárképzés során? (Mi volt jó/nem jó? Esetleg mi hiányzott?)

Főleg a germanisztikai oldal érdekelt, mind major- mind minorszak oldaláról. Erre külön is felhívtam a válaszadók figyelmét. A válaszokból kiderül, hogy a BA képzés csak a föszak esetén nyújtott kellő alapot a mesterszintü tanulmányokhoz, a minor szak viszont nem. Többen megemlítettek konkrét kurzusokat is, amiket különösen hasznosnak találtak (pl. Grammatik, országismeret, nyelvgyakorlatok). Többen viszont hiányolták, hogy a BA során a tanári pályára nem készülhettek fel. Jó lett volna például, ha már korábban lett volna hospitálási lehetőségük, elmenni egy-egy iskolába. Volt, aki kiemelte, hogy pl. az irodalmi kurzusoknak nem sok hasznát látja, bár elismeri, hogy fejlesztik a szövegértési kompetenciát. Azok, akik a németet minor képzésben végezték el, jobban megérezték, hogy az MA képzés nem épült megfelelően a BA képzésre. Szerintük a germanisztika MA programja egyáltalán nem veszi figyelembe a BA minor szak sajátosságait. 
Az MA-tanárképzés során mely kurzusokat érezte fontosnak és szükségesnek jövőbeli tanári munkájához (esetleg miért)? Mely kurzusoknál érezte úgy, hogy az itt tanultakra nincs/nem lesz szüksége?

Itt leginkább arra voltam kíváncsi, hogy - föleg a féléves tanítási gyakorlat után mennyire érzik a végzősök relevánsnak azokat a tartalmakat, illetve tanegységeket, amiket az egyetem nyújtott nekik a mesterképzésben.

A mesterképzésben mindenki kiemelte a szakmódszertani (tantárgy-pedagógiai) kurzusok fontosságát és hasznosságát, szerettek volna ezekböl a kurzusokból többet. Csak néhány esetben neveztek meg olyan foglalkozásokat, amelyeket jövőbeli hivatásuk szempontjából nem éreztek fontosnak. Hiányolták, hogy mesterszinten nincs országismeret, és azt is, hogy a sok irodalomóra egyike se foglalkozott a gyermek- és ifjúsági irodalommal. Volt, aki túlzásnak tartotta pedagógiából a 40 kreditet. És volt, aki úgy gondolta, hogy mindegyik kurzushoz úgy áll hozzá, hogy annak valamilyen haszna lesz később.

A tanitási gyakorlatok során mely kurzusokon tanultakra tudott leginkább támaszkodni? Miért?

A kérdés célja az volt, hogy visszajelzést kapjunk arról, mennyire használták a képzés során elvégzett, sokszor elméleti jellegü kurzusok anyagát a gyakorlatban. Itt újra egyöntetü volt a vélemény, hogy a szakmódszertan az a tárgy, amire a legtöbbször támaszkodtak az iskolai tanítási gyakorlat során. A pedagógiai kurzusok közül meglepően keveset említettek meg a válaszadók (pedagógiai értékelés; család és iskola). Többen meg is jegyezték, hogy a képzés során túlsúlyban voltak az elméleti jellegü órák. A szaktantárgy órái közül is csak néhány válaszadó említett meg egyet-egyet (Grammatik, Wörterbuchbenutzung), de ezek BA-kurzusok voltak.

Szükség van-e az egyetemen tanultakra a gyakorlatban, vagy inkább osztja azt a gyakori véleményt, miszerint a tanári pályára való alkalmasságot nem lehet tanulni, azt csak a gyakorlat során lehet elsajátítani?

Ezt a kérdést azért tartottam szükségesnek, mert az akkreditációs folyamat során többször hallottam ezt a véleményt, leginkább bölcsészek szájából. A válaszolók közt csupán egy volt, aki hasonlóan gondolkodott. Szerinte a tanári mesterséget csak a gyakorlat során lehet elsajátítani, és csak ott dől el, hogy valaki alkalmas-e a pályára. A többiek mind úgy gondolták, hogy szükség van azokra az alapokra, amiket az egyetem ad. Volt, aki velősen ki is fejezte, hogy szerinte „baromság, hogy nem kell az egyetem hozzá". 
Hogy itéli meg az elmélet és gyakorlat arányát a képzésben?

Ezt a kérdést az az érvelés indokolta, hogy a bolognai rendszerü tanárképzés jobban készíti fel a tanárjelölteket hivatásukra, mert erősebben gyakorlatorientált, mint a korábbi képzés. A végzős diákok is úgy gondolták, hogy jó, hogy kétszer van gyakorlat, s a második jóval hosszabb ideig tart. De fogalmaztak meg kritikát is. Van, aki úgy vélte, hogy az egyetem(ek) gyakorlóiskolái (amelyek nyilvánvalóan elitiskolák) nem feltétlen mutatnak valós képet. Szerintük az országban kevés az olyan iskola, mint a Ságvári Általános Iskola vagy Gimnázium ${ }^{8}$ és sokkal több az olyan, ahol vannak hátrányos helyzetü, illetve értelmi, erkölcsi szempontból fejletlen, esetleg SNI-s gyerekek. Így nagyon hasznos tapasztalat volt számukra az összefüggő szakmai gyakorlat, amikor egy olyan iskolába kerültek, amely valószínüleg megközelíti a realitást.

Mit változtatna meg feltétlenül a jelenlegi tanárképzésben és miért? És mi az, amit megtartana? Miért?

Ez volt talán a legizgalmasabb kérdés, jóllehet már biztos volt a válaszadás időpontjában, hogy ez a képzési forma megszünik. Ezt javasolták a válaszadók is, például így: „A többciklusú tanárképzést eltörölném, mert akkor már első évtől kezdve kétszakos tanárképzésben lehetne részesülni és nem lenne a minor és major szak között különbség. Kezdettől fogva a tanári munkához szükséges tárgyakat lehetne tanulni, és nem kellene specializációt választani, aminek kevés köze van a tanításhoz". Növelnék a szakmódszertani kreditek és kurzusok számát is. A gyakorlathoz kapcsolódva többen megjegyzik, hogy a gyakorlati képzés rendszere megfelelő, csak ügyelni kellene arra ,a tanárjelöltek beosztásakor, hogy minden egyes tanárszakos hallgató megismerkedjen az általános iskolai és a középiskolás korosztállyal is, illetve, hogy a gyakorlóiskolákon kívül más iskolákba is be legyen osztva". De a kétszeri gyakorlat igen hasznos volt, „mert tanulhattam a hibáimból és a következő gyakorlat során másképp csinálhattam”. Kritika érte a mentorokat, akik a válaszadók egy része szerint nem voltak kellőképpen felkészítve feladatukra. A mesterképzésre szánt 5 félévet pedig többen túl rövidnek tartották. Az egész tanárképzésre vonatkozóan némely diák túlzónak érezte az elvárásokat: „Sokszor az volt az érzésem a 2,5 év mesterképzés folyamán, hogy a végén kapnom kéne egy germanisztika, egy történész és egy pedagógia szakos diplomát is. Történelemböl tulajdonképpen a 4 szemeszter alatt ugyanazokat a tantárgyakat hallgattam, mint az alapképzésben, ők megismételték önmagukat. Németen ugyan más jellegü kurzusok voltak, de szintén túl tudományosak. Végül ugyanez elmondható a pedagógiáról és a pszichológiáról is." Volt, aki a nyelvi kurzusokat hiányolta a képzés vége felé. Szóba került a gyakorlattal egyidejüleg megírandó portfólió és szakdolgozat is. Ez a kettő igen nagy terhet jelentett némelyik diáknak. (Ez volt az oka annak is, hogy

\footnotetext{
${ }^{8}$ A Szegedi Tudományegyetem gyakorló iskolái.
} 
az eredetileg 20 fös csoportból csak tizenketten tudták öt félév alatt befejezni tanulmányaikat.) Azt pedig sajnálatosnak tartották, hogy ha írnak egy tanári portfóliót, akkor miért nem írhatnak szaktárgyukból „hagyományos” (bölcsész) szakdolgozatot.

\section{Egyéb tapasztalatok}

Az utolsó kérdés teljesen nyitott volt, bármit írhattak ide, ami szerintük tanulságos lehet. Ezeket nehéz lenne összefoglalni, mert ahányan írtak ide valamit, annyiféle véleményt fogalmaztak meg. Némelyik válaszadó megismételte a korábbi kérdések valamelyikére adott válaszát. Így most csak azokat a gondolatokat gyüjtöm össze, amik valami újat tartalmaznak a korábbiakhoz képest.

A megkérdezettek fele állította, hogy az egész BA és MA képzést kaotikusnak élték meg. Mind a tanárok, mind a Tanulmányi Osztályon dolgozók bizonytalanok voltak, és konkrét dolgokat sokszor későn, csak utólag tudtak meg. Szintén a csoport fele úgy látta, hogy a mentorok nem voltak egészen tisztában azzal, hogy mit kell nekik kezdeniük a tanárjelöltekkel a gyakorlat során.

Kritikaként merült fel az is, hogy a különböző tanszékek programját nehezen lehetett összehangolni a pedagógiai és pszichológiai tanszékekkel. Sok probléma, félreértés adódott abból is, hogy mást várt el, mást követeltek az előbbi tanszékek és mást a szaktanszék. Az ebből adódó félreértések elkerülésével vonzóbbá lehetett volna tenni a képzést a hallgatók számára.

Néhány pozitív visszajelzés is előfordult, ez mindig egy-egy válaszadót érintett. Egy diák örömét fejezte ki, hogy elnyert egy DAAD ösztöndíjat ${ }^{9}$. Egy másik hallgató arról számolt be, hogy a szakmódszertani kurzuson szóba került egyszer a Comenius tanárasszisztensi pályázat, amire sikeresen jelentkezett. Ezek a lehetőségek azonban függetlenek voltak a bolognai képzési rendszertől.

\section{5. Összegzés és kitekintés}

A bolognai rendszerrel kapcsolatban leginkább 2009 és 2011 között jelentek meg írások, amik általában vázolták az előnyöket és hátrányokat (pl. Pálffy 2010), de az egyes szakképzésekre gyakorolt hatását nem vizsgálták. Ha meg is jelent írás egy-egy szakterülettel kapcsolatban, az leginkább a müszaki és természettudományos képzésre vonatkozott. A Felsőoktatási Mühely 2010/1 száma a bolognai folyamat első évtizedét vette górcső alá, de ebben főleg a külföldi tapasztalatokra hagyatkozott. Olyan forrást nem sikerült eddig találnom, amelyik a nyelvtanárképzésre gyakorolt hatását tárta volna fel. Saját kísérletem is csupán egyetlen intézmény egyetlen évfolyamára vonatkozik. Az első képzési ciklus végén 12 fővel végzett felmérésből természetesen nem lehet messzemenő következtetéseket leszürni. Mégis, úgy gondolom, nem volt egészen

\footnotetext{
${ }^{9}$ Deutscher Akademischer Austauschdienst (Német Felsőoktatási Csereszolgálat)
} 
haszontalan a végzősök megkérdezése. A 2012 decemberében és 2013 januárjában megírt válaszokból egyértelmüen kiderül, hogy a kapkodva, átgondolatlanul és nem kellően előkészített bolognai rendszer nem igazán müködött jól. A záróvizsgához leadott tanári portfóliókban részletesen is visszajelzést kaphattam a képzés számos problémájáról. Ez külön elemzés tárgyát képezhetné. A kérdés azonban most már az, hogy azok, akik az újra osztatlan tanárképzést indítják útjára, meg tudják-e oldani úgy a feladatot, hogy az mind a diákok, mind az oktatók megelégedésével folyhasson. Ehhez szerintem szükséges (lenne) a képzés folyamatos monitorozása és szükség esetén korrigálása.

\section{Irodalom}

Bárdos. J. \& Medgyes, P. (1997). A hároméves angoltanár-képzés továbbfejlesztésének lehetőségei: 1994-96. Modern Nyelvoktatás 3(1-2), 3-19.

Krumm, H.-J. (1996). Fremdsprachen in Wissenschaft und Unterricht: die mißlingende Ankunft. In K.-R. Bausch, H. Christ, F. G. Königs \& H.-J. Krumm (szerk.), Erforschung des Lehrens und Lernens fremder Sprachen. Zwischenbilanz und Perspektiven. (pp. 96104). Tübingen: Gunter Narr Verlag.

Pálffy, D. (2010). A Többciklusú Képzési Rendszer értékelése hallgatói szemmel. keszei.chem.elte.hu/Bologna/ELTE_EHOK.doc (megtekintés dátuma: 2014.10.28).

Petneki, K. Schmitt, W. \& Szablyár, A. (szerk.) (1994). Curriculumevaluation der Deutschlehrerausbildung aus didaktischer Sicht. Tagungsdokumentation. (Budapester Beiträge zur Germanistik, Band 25). Budapest: ELTE.

Rösler, D. (2001). Lehren und Lernen von Deutsch als Fremdsprache in der europäischen Auslandsgermanistik. In G. Helbig, L. Götze, G. Henrici, Gert \& H.-J. Krumm (szerk.), Deutsch als Fremdsprache. 2. Handbücher zur sprach- und Kommunikationswissenschaft (pp. 1151-1159). Berlin: Walter de Gruyter.

Szépe, Gy. (1997). A hároméves nyelvtanári program folytatása a IV. és V. évben. Modern Nyelvoktatás 3(4), 42-46.

Tanári mesterképzési szak. A 15/2006 (IV. 3.) OM rendelet 4. sz. melléklete. http://jogszabalykereso.mhk.hu/cgi_bin/njt_doc.cgi?docid=101032 (megtekintés dátuma: 2014. 10.28). 